\title{
24. GEOCHEMISTRY OF CARBON: DEEP SEA DRILLING PROJECT, LEGS 47A AND B
}

\author{
J. G. Erdman and K. S. Schorno, Phillips Petroleum Company, Bartlesville, Oklahoma
}

\section{INTRODUCTION}

As part of the deep continental margins study of the International Phase of Ocean Drilling (IPOD), we obtained 58 frozen core sections for geochemical investigation. These samples consist of Pleistocene through Lower CretaceousBarremian sediments from Holes 397, 397A, and 398D on the outer continental margins off northwestern Africa and west of Portugal in the North Atlantic (see Figure 1).

\section{SAMPLING AND STUDY PROCEDURES}

In most instances, only quarter-sections of each core were available for study; consequently, the visual inspection usually performed in this laboratory for determining drilling disturbance and possible contamination on half-sections of core was not possible. The samples were separated and characterized as shown in Figure 2. Core samples were air dried at $60^{\circ} \mathrm{C}$ for 24 hours and crushed and sieved to $150 \mu \mathrm{m}$. A 2-gram portion of homogenized core was analyzed for organic and carbonate carbon, and ammonium and total nitrogen. The crushed, dried sediment (approximately $100 \mathrm{~g}$ ) was extracted by treating with methylene chloride for 24 hours. The methylene chloride was removed on a $60^{\circ} \mathrm{C}$ constant temperature bath under a stream of nitrogen, yielding an oil extract which hereafter is designated the lipid fraction.

Carbon isotopic compositions were determined on the lipid and kerogen fractions. These measurements were made by the closed-loop combustion method on an AVCO isotope ratio mass spectrometer.

Because of the sparsity of soluble organic matter within these sediments, the only additional analysis performed on the extracts was a gas chromatographic profile on the $n$-heptane soluble lipid. We determined these profiles with a Perkin-Elmer 3920 on a 12 -foot $\times 1 / 8$-inch 3 per cent Dexsil 300 on $100 / 120$ mesh Suplecoport column.

\section{RESULTS}

Table 1 provides the geologic age, sub-bottom depth, and numerical data generated for these samples.

\section{Holes 397 and 397A}

Holes 397 and 397A are in a water depth of 2900 meters on the uppermost continental rise west-northwest of Cape Bojador, northwestern Africa. We studied 15 frozen core samples from these holes, ranging from Pleistocene to Lower Cretaceous and encompassing sub-bottom depths of 16.2 to 1444.5 meters. These samples represent all three major lithostratigraphic units defined by the shipboard party.

\section{Unit 1}

We studied nine core samples ranging from Pleistocene to upper Miocene and between depths of 16.2 and 648.5 meters. These cores are predominantly hemipelagic marly nan-

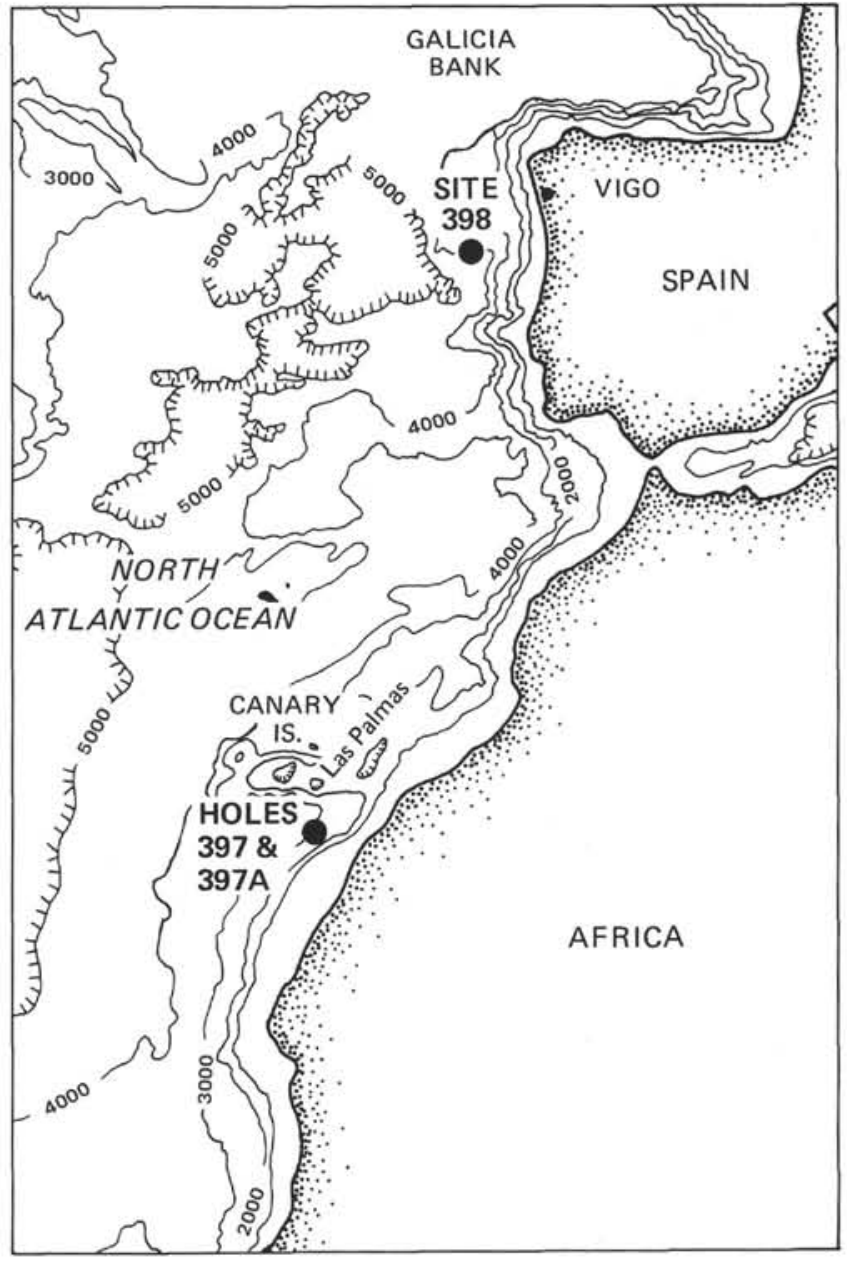

Figure 1. Location of Holes 397, 397A, and 398D from which samples were obtained for geochemical study.

nofossil oozes. The carbonate content, which hereafter will be reported as calcium carbonate, averages 60 per cent and ranges from 42 to 75 per cent.

The ammonium nitrogen content from Unit 1 sediments varies from 43 to $196 \mathrm{ppm}$ and averages $91 \mathrm{ppm}$. This is comparable to determinations of deep oceanic carbonates, low in organic matter, that were recovered on previous DSDP cruises, e.g., the $88 \mathrm{ppm}$ average for the Leg 40 Miocene to Eocene carbonates from the Cape Basin (Erdman and Schorno, 1978). The organic nitrogen content is greater than expected for sediments that are low in organic matter, averaging $591 \mathrm{ppm}$ in these samples compared to $272 \mathrm{ppm}$ for Leg 40 carbonates.

The organic content averages 0.4 per cent, slightly lower than noted in the shipboard reports, and ranges from a high of 0.9 per cent at the top of the section to a low of 0.2 per cent 


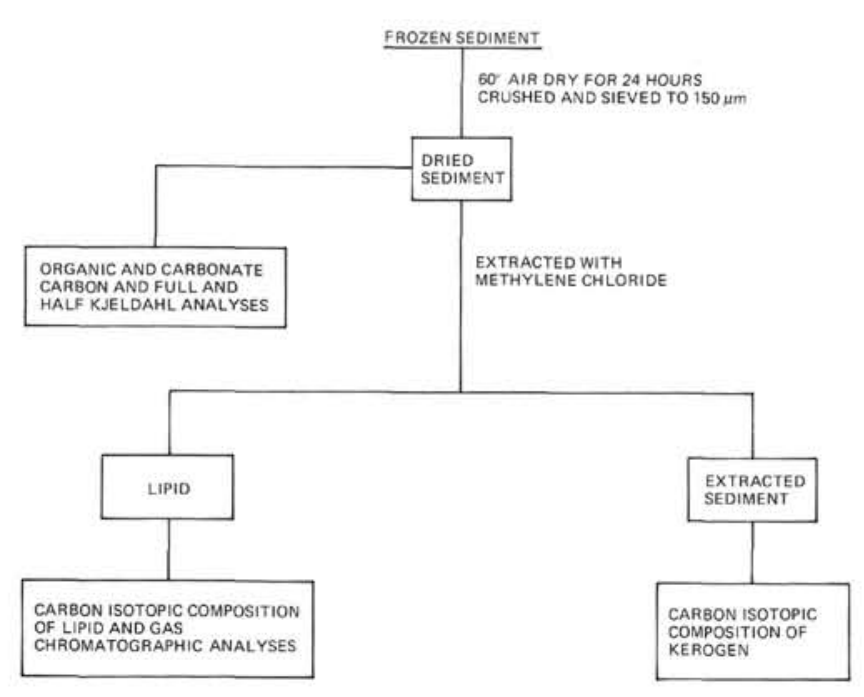

Figure 2. Flow sheet for the separation and characterization of organic matter from IPOD cores from Leg $47 \mathrm{~A}$ and $B$.

toward the bottom. The organic carbon content exceeds 0.5 per cent only in the Pleistocene. Similarly, the lipid carbon content of the Pleistocene is larger than for remaining sediments in this unit, averaging $64 \mathrm{ppm}$. The lipid content decreases with increasing depth and age to a low of $6 \mathrm{ppm}$ in the lower Pliocene, and remains low throughout the remainder of Unit 1 . In general, the ratio of lipid to total organic carbon is low throughout the unit, averaging only 0.6 per cent.

Except for lowermost Section 397-68-2, the gas chromatographic (GC) profile of the $n$-heptane soluble portion of the lipid fraction for Unit 1 is typified by the chromatograms of Sections 397-6-3 and 397-29-3 shown in Figure $3 \mathrm{a}, \mathrm{b}$. These samples have a large odd-carbon predominance of $n$-alkanes in the $\mathrm{C}_{27}$ to $\mathrm{C}_{31}$ range, only one unresolved carbon maximum at $\mathrm{C}_{27}$, a major peak (designated as $A$ on the chromatogram) between $C_{20}$ and $C_{21}$, and two minor components at $\mathrm{C}_{24}$ and $\mathrm{C}_{26}$ ( $\mathrm{B}$ and $\mathrm{C}$, respectively). Differences are notable in the relative abundance of Peaks A, B, C, and D. The GC profile for Section 397-18-5 contains a major peak at B (doublet) and minor peaks at A, C, and $\mathrm{D}\left(\mathrm{C}_{28}\right)$. The profile for Section 397-68-2 (Figure $3 \mathrm{c}$ ) shows a strong odd predominance of $n$-alkanes in the $\mathrm{C}_{25}$ to $\mathrm{C}_{32}$ range, with a maximum at $\mathrm{C}_{29}$. In addition, this chromatogram shows a bimodal unresolved maxima and a large $\mathrm{C}_{19}$ component, which probably indicates a mixture of $n-\mathrm{C}_{19}$ and another compound. Peaks $\mathrm{A}$ and $\mathrm{C}$ have similar retention times as dibutyl and dioctyl phthalates. All four components (A, B, C, and D) may be plasticizer contaminates; the irregular occurrence of each peak or combination of peaks, however, indicates that either they are not contaminates or there is a multiple source of contamination.

The carbon isotopic composition of the lipid varies throughout Unit 1. For lipid carbon from the Pleistocene sediments, this composition averages $-24.6 \pm 0.4 \delta^{13} \mathrm{CPDB}_{\text {; }}$ the upper Pliocene to uppermost lower Pliocene averages $-28.3 \pm 0.3 \delta^{13} \mathrm{CPDB}_{\text {; }}$ and the lowermost Pliocene to the middle Miocene averages $-24.8 \delta^{13}$ CPDB. The light isotopic value for the upper Pliocene to uppermost lower Pliocene indicates a large increase of terrigenous organic matter to the marine sediments; this also is reflected in an increase in land-derived clastics as noted in the shipboard reports.

\section{Unit 2}

The five lower Miocene core samples that we obtained from Unit 2 represent depths of 907.5 to 1167.9 meters. The samples consist of more slowly deposited hemipelagic foraminiferal nannofossil marlstones to calcareous mudstones. The carbonate content averages 25 per cent and ranges from 5 to 31 per cent.

The ammonium and organic nitrogen contents (averaging 274 and $830 \mathrm{ppm}$, respectively) are slightly higher than in Unit 1 (i.e., 91 and $591 \mathrm{ppm}$ ).

The low organic content continues into the uppermost lower Miocene and then increases gradually to a high of 1.21 per cent in the lowermost Miocene. Similarly, the lipid content is low in the middle Miocene and increases gradually to a high of $179 \mathrm{ppm}$ in the lowermost Miocene. The ratio of lipid to total organic carbon is also low for the middle Miocene and generally increases with depth to a maximum of 1.15 per cent at the bottom of the unit.

The profiles of Sections 397-95-4, 397A-12-2, and 397A-16-4 similarly show major peaks at A and B, and a possible smooth $n$-alkane distribution from $\mathrm{C}_{26}$ to $\mathrm{C}_{33}$. Sections 397A-21-2 and 397A-23-4 contain similar profiles between $\mathrm{C}_{16}$ to $\mathrm{C}_{20}$, but differ in the higher range. The profile of Section 397A-51-4 shows no similarities to previous profiles from this unit. Sections 397A-31-2 and 397A-51-4 have a predominance of odd-numbered $n$-alkanes.

The carbon isotopic composition of the lipid is nearly constant throughout the lower Miocene to a depth of 1072.8 meters (averaging $-28.8 \delta^{13} \mathrm{C}$ PDB with a range from -29.7 to $\left.-27.2 \delta^{13} \mathrm{C}_{\mathrm{PDB}}\right)$, and increases to $-24.2 \pm 0.4 \delta^{13} \mathrm{CPDB}_{\mathrm{PD}}$ in the lowermost Miocene at a depth between 1126.5 and 1167.5 meters. The carbon isotopic compositions of the kerogen are constant for Unit 2 and averae $-21.2 \pm 1.3 \delta^{13}$ СРDB, which is similar to the average for Unit 1 .

\section{Unit 3}

The mudstone core sample from the Lower Cretaceous has a carbonate content of 4.5 per cent and an organic carbon content of 0.98 per cent. The ammonium and organic nitrogen contents are 161 and $1008 \mathrm{ppm}$, respectively; these values are typical of deep oceanic sediments which are rich in organic matter. The lipid content ( $248 \mathrm{ppm})$ is large. The carbon isotopic compositions of the lipid and kerogen are -26.9 and $-23.8 \delta^{13}$ СРDB, respectively.

\section{Hole 398D}

Hole $398 \mathrm{D}$ is at a water depth of 3890 meters on the continental margin of the eastern North Atlantic, west of Portugal. The 43 frozen core samples that we studied span from Miocene to Barremian in the Lower Cretaceous and range from 322.7 and 1665.3 meters in sub-bottom depth. Of the five major lithologic units found in Hole 398, we obtained samples from Units 1 through 4.

\section{Unit 1}

We studied six Unit 1 samples, predominantly marly nannofossil oozes to siliceous marly chalks, ranging from upper 
Miocene to upper Oligocene. The carbonate content averages 66.1 per cent and ranges from 30.9 to 86.4 per cent.

Both the ammonium and organic nitrogen contents (averaging 40 and $268 \mathrm{ppm}$, respectively) are low, as are the organic and lipid contents of these carbonates. The organic carbon averages 0.09 per cent and ranges from 0.04 to 0.12 per cent; the lipid content averages $8 \mathrm{ppm}$ and ranges from 3.9 to $20.3 \mathrm{ppm}$. The ratio of lipid to total carbon (which ranges from 1 to $3 \%$ in most deep oceanic sediments) is low $(0.5 \%$ average $)$ in the 322.7 to 517.0 -meter interval, and increases (to $5.1 \%$ ) in the lower Miocene-upper Oligocene at 552.3 meters. The 552.3-meter Section $15-4$ is low in organic carbon $(0.04 \%)$.

With the exception of Section 398D-3-3, the GC profiles for Unit 1 core samples are similar to that of Section 398D8-2, shown in Figure $3 \mathrm{~d}$. In each profile, a smooth progression of $n$-alkanes is observed from $\mathrm{C}_{17}$ to $\mathrm{C}_{20}$, with oddnumbered predominance in the $\mathrm{C}_{27}$ to $\mathrm{C}_{31}$ range.

The carbon isotopic composition of the lipid for this unit is relatively constant, averaging $-26.8 \delta^{13}$ CPDB with a range between -26.1 and $27.7 \delta^{13}$ СPDB. The carbon isotopic composition of the kerogen is high (with an average value of $-24.6 \pm 0.4 \delta^{13} \mathrm{CPDB}_{\mathrm{P}}$ ) from the top of the unit to the middle Miocene at 419.5 meters, and then decreases (averaging $-26.4 \pm 1.4 \delta^{13}$ С $\mathrm{PDB}$ ) in the lower Miocene below 454.2 meters.

\section{Unit 2}

These six samples are calcareous mudstones to siliceous marly chalks. These sediments range from lower Oligocene/upper Eocene to upper Paleocene, and from 588.8 to 760.0 meters. The carbonate content of these samples is relatively low (ranging from 19 to $31 \%$ ) at the top of the unit, and increases (to $81 \%$ ) at the bottom.

The ammonium and organic nitrogen contents (averaging 56 and $301 \mathrm{ppm}$, respectively) are similar to those of Unit 1, and the organic and lipid contents are similarly low. The organic content increases slightly with depth from 0.1 to 0.48 per cent. The lipid content is relatively constant throughout the unit and averages $10 \mathrm{ppm}$, with the exception of upper Paleocene sediments $(759.8 \mathrm{~m})$ where it increases to $59 \mathrm{ppm}$.

The per cent of the total carbon as lipid is generally low, averaging 1.0 per cent. Of the six core samples studied in this unit, only two contain lipid to total carbon ratios greater than 1.0 per cent and both contain less than 0.5 per cent organic carbon.

The GC profiles of Sections 398D-19-3 through 398-37-3 are similar to the profile shown in Figure $3 \mathrm{e}$. Each sample has a smooth $n$-alkane distribution from $\mathrm{C}_{17}$ to $\mathrm{C}_{20}$, an oddnumbered predominance from $\mathrm{C}_{27}$ to $\mathrm{C}_{31}$, and an unresolved carbon maximum at $\mathrm{C}_{27}$. There are differences in the ratios of Peaks A, B, and C; in the case of Section 398D-23-2, one peak $(\mathrm{E})$ is centered between $\mathrm{C}_{22}$ and $\mathrm{C}_{23}$.

The carbon isotopic composition of the lipid fraction is relatively constant, averages $-26.0 \delta^{13} \mathrm{CPDB}_{\mathrm{PD}}$, and ranges from -26.6 to $-27.1 \delta^{13}$ СРDв. These values are similar to values from Unit 1 samples. The carbon isotopic composition of the kerogen is relatively constant and averages $-27.5 \delta^{13} \mathrm{CPDB}_{\mathrm{PD}}$ with a range of -28.4 to $-26.5 \delta^{13}$ CPDB. This average value is lighter than the average for the lipids by $1.5 \delta$ units, and lighter than the kerogen fraction of Unit 1 by as much as $2 \delta$ units.

\section{Unit 3}

We studied four core samples ranging from Paleocene to Campanian, and from 789.0 to 913.6 meters. These cores consist of calcareous mudstones alternating with a marly chalk that grades downward to red barren mudstone. The carbonate content is relatively high at the top of the unit with a range from 33 to 48 per cent, and then decreases to 0.2 to 3 per cent at the bottom.

The ammonium and organic nitrogen contents are low (averaging 64 and $275 \mathrm{ppm}$, respectively) and similar to the two units above. The organic and lipid carbon contents are also low, with averages of 0.07 per cent and $28 \mathrm{ppm}$, respectively. This unit's ratio of the lipid to total organic carbon is predominantly higher (averaging $4.3 \%$ ) than for the upper two units. Even though the amount of lipid carbon is greater in this unit, the total amount of lipid is still small and below the amount expected for uncompacted sediments.

All four cores contain GC profiles similar to that of Section 398D-48-3, shown in Figure 3f. Each contains a regular progression of $n$-alkanes from $\mathrm{C}_{16}$ to $\mathrm{C}_{20}$, a predominance of odd-numbered $n$-alkanes from $\mathrm{C}_{27}$ to $\mathrm{C}_{33}$, and an unresolved carbon maximum at $\mathrm{C}_{27}$. Differences are observed in the ratio of Peaks A, B, C, and D.

The isotopic composition of the lipid averages -26.5 $\delta^{13} \mathrm{CPDB}_{\mathrm{PD}}$, ranges from -25.6 to $-27.4 \delta^{13} \mathrm{CPDB}_{\mathrm{PD}}$ and is similar to the values obtained for both Units 1 and 2 . The carbon isotopic composition of the kerogen averages $-27.4 \pm 0.3$ $\delta^{13} \mathrm{CPDB}$, and is $1 \delta$ unit lighter than the lipid carbon.

\section{Unit 4}

The 27 core samples from Unit 4 range from Cenomanian through Barremian. Over a depth interval of 960.4 to 1665.3 meters, these sediments vary in lithology from dark laminated marls to claystone that grades down into dark organic shales. The carbonate content is high (averaging 36\%) above 1037 meters at the top of the unit, then decreases sharply (to an average value of $3.5 \%$ ) from the Albian at 1073.4 meters to the Aptian at 1313.0 meters, varies $(<0.8$ to $3 \%)$ in the remaining Aptian, and then increases slightly (to an average value of $18 \%$ ) in the Barremian.

The ammonium content averages $84 \mathrm{ppm}$ between depths of 960.4 to 1073.5 meters, increases to an average of 125 ppm in Barremian sediments down to a depth of 1570.6 meters, then decreases to $67 \pm 6 \mathrm{ppm}$ for the remainder of the unit. The organic nitrogen varies considerably throughout the unit, from a low of 271 to a high of $1550 \mathrm{ppm}$, with an average of $615 \mathrm{ppm}$. In general, the ammonium and organic nitrogen contents are higher in this unit than in the overlying units.

The organic carbon content in the depth interval between 960.4 and 1037.0 meters is below 0.5 per cent, increases to a high of 2.6 per cent at 1139.6 meters, and then remains relatively high with a 1 per cent average throughout the remainder of Unit 4. Except for the 1139.6-meter Section 398D-75-2, which contains 100 ppm lipid carbon, the lipid carbon content is low throughout the unit, and averages 19 ppm. Similarly, the percent of the total organic carbon as lipid is low, averaging 0.3 per cent.

The GC profile of Section 398D-57-4 at the top of Unit 4 is similar to those from Unit 3, with the exceptions of a slight odd-to-even $n$-alkane preference from $\mathrm{C}_{16}$ to $\mathrm{C}_{20}$ and only one major peak (component A). Samples from 398D-65-4 
TABLE 1

Chemical Analyses for Site 397 and 398 Sediments

\begin{tabular}{|c|c|c|c|c|c|c|c|c|c|c|c|c|c|}
\hline \multirow[b]{3}{*}{$\begin{array}{l}\text { Hole-Core } \\
\text { Section }\end{array}$} & \multirow[b]{3}{*}{ Geologic Age } & \multirow[b]{3}{*}{$\begin{array}{l}\text { Sub-Bottom } \\
\text { Depth (m) }\end{array}$} & \multirow{2}{*}{\multicolumn{2}{|c|}{ Carbonate }} & \multirow{2}{*}{\multicolumn{2}{|c|}{ Organic Carbon }} & \multirow{3}{*}{$\begin{array}{l}\text { Lipid/Total } \\
\text { Organic C } \\
\text { (wt. \%) }\end{array}$} & \multirow{2}{*}{\multicolumn{3}{|c|}{$\begin{array}{l}\text { Carbon Isotopic Composition } \\
\qquad{ }^{13} \mathrm{C}_{\mathrm{PDB}}\end{array}$}} & \multicolumn{3}{|c|}{ Kjeldahl Nitrogen (ppm) } \\
\hline & & & & & & & & & & & (Half) & (Full) & (Full-Half) \\
\hline & & & $\begin{array}{l}\text { Carbon } \\
\text { (wt. \%) }\end{array}$ & $\begin{array}{l}\mathrm{CaCO}_{3} \\
\text { (wt. \%) }\end{array}$ & $\begin{array}{l}\text { Total } \\
\text { (wt. \%) }\end{array}$ & $\begin{array}{l}\text { Lipid } \\
(\mathrm{ppm})\end{array}$ & & Lipid & Kerogen & $\begin{array}{l}\text { Diff. } \\
\text { L-K }\end{array}$ & Ammonium & Total & Organic \\
\hline \multicolumn{14}{|l|}{ Leg 47A } \\
\hline \multicolumn{14}{|c|}{ Unit 1} \\
\hline $397-2-5$ & Pleistocene & $16.2-16.5$ & 9.0 & 74.8 & 0.71 & 61 & 0.85 & -24.9 & -20.4 & -4.5 & 57 & 673 & 616 \\
\hline $397-6-3$ & Pleistocene & $51.2-51.5$ & 5.4 & 45.1 & 0.85 & 64 & 0.75 & -24.0 & -19.9 & -4.1 & 104 & 1064 & 960 \\
\hline $397-10-6$ & Pleistocene & $92.5-93.0$ & 7.3 & 60.4 & 0.44 & 40 & 0.91 & -25.0 & -20.0 & -5.0 & 79 & 730 & 651 \\
\hline $397-18-5$ & U. Pliocene & $168.0-168.5$ & 6.6 & 54.9 & 0.32 & 7 & 0.21 & -28.0 & -20.4 & -7.6 & 120 & 714 & 594 \\
\hline $397-29-3$ & L. Pliocene & $269.5-270.0$ & 8.9 & 74.2 & 0.16 & 6 & 0.35 & -28.6 & -20.8 & -7.8 & 94 & 496 & 402 \\
\hline $397-32-2$ & L. Pliocene & 296.8-297.0 & 8.0 & 66.9 & 0.28 & 40 & 1.41 & -23.8 & -21.8 & -2.0 & 43 & 540 & 497 \\
\hline $397-45-4$ & U. Miocene & $423.2-423.5$ & 8.0 & 66.9 & 0.26 & 12 & 0.48 & -24.3 & -22.0 & -2.3 & 43 & 569 & 526 \\
\hline $397-52-3$ & U. Miocene & $497.5-498.0$ & 6.7 & 55.8 & 0.31 & 15 & 0.47 & -25.1 & -20.9 & -4.2 & 86 & 521 & 435 \\
\hline $397-68-2$ & M. Miocene & $648.2-648.5$ & 5.1 & 42.3 & 0.38 & 7 & 0.18 & -25.8 & -25.1 & -0.7 & 196 & 830 & 634 \\
\hline \multicolumn{14}{|c|}{ Unit 2} \\
\hline $397-95-4$ & L. Miocene & $907.5-908.0$ & 0.6 & 4.8 & 0.21 & 15 & 0.72 & -29.7 & -22.5 & -7.2 & 187 & 591 & 404 \\
\hline $397 A-12-2$ & L. Miocene & $1031.5-1032.0$ & 3.1 & 25.8 & 0.80 & 16 & 0.19 & -27.2 & -21.2 & -6.0 & 423 & 1526 & 1103 \\
\hline $397 A-16-4$ & L. Miocene & $1072.5-1072.8$ & 3.6 & 30.2 & 0.87 & 37 & 0.42 & -29.6 & -20.1 & -9.5 & 389 & 1603 & 1214 \\
\hline $397 \mathrm{~A}-21-2$ & L. Miocene & $1127.7-1128.0$ & 3.7 & 30.9 & 0.44 & 48 & 1.10 & -24.6 & -22.3 & -2.3 & 139 & 618 & 479 \\
\hline $397 \mathrm{~A}-23-4$ & L. Miocene & $1167.6-1167.9$ & 3.8 & 31.3 & 1.21 & 180 & 1.15 & -23.8 & -20.0 & -3.8 & 234 & 1186 & 952 \\
\hline \multicolumn{14}{|c|}{ Unit 3} \\
\hline $397 A-514$ & L. Cretaceous & $1444.4-1444.5$ & 0.5 & 4.5 & 0.98 & 248 & 2.53 & -26.9 & -23.8 & -3.1 & 161 & 1169 & 1008 \\
\hline \multicolumn{14}{|l|}{ Leg 47B } \\
\hline \multicolumn{14}{|c|}{ Unit 1} \\
\hline 398D-3-3 & U. Miocene & $322.7-323.0$ & 7.9 & 65.7 & 0.10 & 8 & 0.78 & -26.3 & -24.7 & -1.6 & 14 & 432 & 418 \\
\hline $398 D-5-3$ & M. Miocene & $398.8-399.0$ & 8.8 & 73.6 & 0.11 & 5 & 0.44 & a & -24.8 & & 47 & 320 & 273 \\
\hline $398 D-6-4$ & M. Miocene & $419.3-419.5$ & 10.4 & 86.4 & 0.09 & 4 & 0.47 & -27.7 & -24.2 & -3.5 & 76 & 208 & 132 \\
\hline 398D-8-2 & L. Miocene & $454.2-454.5$ & 8.1 & 67.8 & 0.10 & 4 & 0.38 & -27.0 & -27.3 & 0.3 & 32 & 263 & 231 \\
\hline $398 \mathrm{D}-12-3$ & L. Mio/U. Olig. & $516.7-517.0$ & 3.7 & 30.9 & 0.12 & 7 & 0.60 & -26.1 & -25.0 & -1.1 & 33 & 418 & 385 \\
\hline $398 \mathrm{D}-15-4$ & L. Mio./U. Olig. & $552.3-552.5$ & 8.7 & 72.2 & 0.04 & 20 & 5.08 & a & -26.8 & & 38 & 206 & 168 \\
\hline \multicolumn{14}{|c|}{ Unit 2} \\
\hline 398D-19-3 & L. Olig./L. Eoc. & $588.8-589.0$ & 3.8 & 31.3 & 0.10 & 8 & 0.76 & -25.8 & -28.4 & 2.6 & 47 & 339 & 292 \\
\hline $398 \mathrm{~A}-23-2$ & U. Eocene & $625.1-625.5$ & 2.4 & 20.2 & 0.15 & 9 & 0.63 & -25.9 & -27.3 & 1.4 & 57 & 377 & 320 \\
\hline $398 D-27-2$ & M. Eocene & $663.3-663.5$ & 4.8 & 39.8 & 0.06 & 13 & 2.22 & -24.6 & -27.4 & 2.8 & 46 & 320 & 274 \\
\hline $398 \mathrm{D}-31-3$ & M. Eocene & $702.8-703.0$ & 2.3 & 19.4 & 0.34 & 10 & 0.30 & -26.6 & -27.9 & 1.3 & 43 & 378 & 335 \\
\hline $398 D-33-3$ & L. Eocene & $721.8-722.0$ & 6.0 & 50.2 & 0.14 & 8 & 0.57 & -25.7 & -27.6 & 1.9 & 68 & 361 & 293 \\
\hline $398 D-37-3$ & U. Paleocene & $759.8-760.0$ & 9.7 & 80.7 & 0.48 & 59 & 1.23 & -27.1 & -26.5 & -0.6 & 73 & 366 & 293 \\
\hline \multicolumn{14}{|c|}{ Unit 3} \\
\hline $398 \mathrm{D}-40-4$ & L. Paleocene & $789.7-790.0$ & 4.0 & 33.2 & 0.07 & 85 & 12.20 & -27.4 & -27.2 & -0.2 & 74 & 312 & 238 \\
\hline $398 \mathrm{D}-44-4$ & L. Paleo./Maest. & $827.7-828.0$ & 5.7 & 47.5 & 0.10 & 8 & 0.76 & -25.6 & -27.6 & 2.0 & 46 & 338 & 292 \\
\hline $398 \mathrm{D}-48-3$ & Maest./Campanian & $864.3-864.5$ & $<0.1$ & 0.2 & 0.02 & 5 & 2.51 & -26.9 & -27.7 & 0.8 & 86 & 335 & 249 \\
\hline $398 D-53-4$ & Maest./Campanian & $913.2-913.6$ & 0.3 & 2.8 & 0.08 & 13 & 1.57 & -26.2 & -27.2 & 1.0 & 49 & 369 & 320 \\
\hline
\end{tabular}


Leg 47B- Continued

\begin{tabular}{|c|c|c|c|c|c|c|c|c|c|c|c|c|c|}
\hline $398 D-57-4$ & Cenomanian & $960.4-960.5$ & 4.1 & 34.1 & 0.33 & 10 & 1.04 & -28.8 & -25.1 & -3.7 & 79 & 471 & 392 \\
\hline $398 D-62-4$ & Albian & $1008.2-1008.5$ & 4.7 & 38.8 & 0.39 & 36 & 0.93 & -28.2 & -25.7 & -2.5 & 77 & 448 & 371 \\
\hline $398 D-65-4$ & Albian & $1036.5-1037.0$ & 4.3 & 35.8 & 0.28 & 12 & 0.43 & -28.5 & -25.3 & -3.2 & 99 & 370 & 271 \\
\hline $398 \mathrm{D}-69-2$ & Albian & $1073.4-1073.5$ & 1.0 & 8.5 & 0.51 & 33 & 0.64 & -28.6 & -24.8 & -3.8 & 79 & 686 & 607 \\
\hline $398 D-73-4$ & Albian & $1122.2-1122.5$ & 0.5 & 3.8 & 0.60 & 26 & 0.42 & -28.9 & -24.8 & -4.1 & 125 & 522 & 397 \\
\hline $398 \mathrm{D}-75-2$ & Albian & $1139.6-1140.0$ & 0.3 & 2.2 & 2.64 & 100 & 0.38 & -30.4 & -26.3 & -4.1 & 125 & 1675 & 1550 \\
\hline $398 \mathrm{D}-77-4$ & Albian & $1169.5-1170.0$ & 0.3 & 2.5 & 0.92 & 21 & 0.23 & -28.6 & -24.2 & -4.4 & 107 & 675 & 568 \\
\hline $398 \mathrm{D}-80-2$ & Aptian & $1195.0-1195.5$ & 0.6 & 5.0 & 0.98 & 19 & 0.19 & -28.5 & -23.9 & -4.6 & 133 & 834 & 701 \\
\hline $398 \mathrm{D}-81-2$ & Aptian & $1204.0-1204.5$ & 1.0 & 7.9 & 0.87 & 10 & 0.12 & -29.2 & -24.9 & -4.3 & 115 & 876 & 761 \\
\hline $398 \mathrm{D}-84-4$ & Aptian & $1235.0-1235.5$ & $<0.1$ & 0.6 & 0.50 & 11 & 0.21 & -28.2 & -24.9 & -3.3 & 116 & 587 & 471 \\
\hline $398 D-86-4$ & Aptian & $1255.5-1256.0$ & 0.1 & 1.2 & 0.86 & 19 & 0.22 & -29.1 & -23.1 & -6.0 & 156 & 691 & 535 \\
\hline $398 \mathrm{D}-88-4$ & Aptian & $1273.5-1274.0$ & 0.2 & 1.3 & 0.87 & 8 & 0.09 & -28.7 & -24.1 & -4.6 & 129 & 769 & 640 \\
\hline $398 D-90-5$ & Aptian & $1293.5-1294.0$ & 0.2 & 1.6 & 1.09 & 17 & 0.16 & -28.5 & -23.3 & -5.2 & 108 & 786 & 678 \\
\hline $398 D-92-5$ & Aptian & $1312.5-1313.0$ & $<0.1$ & $<0.8$ & 1.16 & 10 & 0.09 & -28.3 & -22.5 & -5.8 & 131 & 694 & 563 \\
\hline $398 \mathrm{D}-95-3$ & Aptian & $1330.5-1331.0$ & 0.2 & 1.8 & 1.73 & 24 & 0.14 & -29.6 & -22.9 & -6.7 & 146 & 944 & 798 \\
\hline $398 D-97-3$ & Aptian & $1347.5-1348.0$ & $<0.1$ & $<0.8$ & 1.84 & 22 & 0.12 & -28.9 & -22.7 & -6.2 & 157 & 927 & 770 \\
\hline $398 D-99-4$ & Aptian & $1368.0-1368.5$ & $<0.1$ & $<0.8$ & 1.41 & 15 & 0.11 & -27.9 & -22.7 & -5.2 & 154 & 770 & 616 \\
\hline $398 \mathrm{D}-101-3$ & Aptian & $1385.7-1386.3$ & $<0.1$ & $<0.8$ & 1.26 & 7 & 0.06 & -28.3 & -22.7 & -5.6 & 122 & 702 & 580 \\
\hline 398D-103-4 & Aptian & $1406.0-1406.5$ & 0.3 & 2.3 & 0.90 & 7 & 0.08 & -27.2 & -21.6 & -5.6 & 114 & 639 & 525 \\
\hline $398 D-106=5$ & Aptian & $1437.0-1437.5$ & 0.3 & 2.4 & 0.87 & 10 & 0.11 & $-27,0$ & -21.8 & -5.2 & 138 & 557 & 419 \\
\hline $398 \mathrm{D}-108-3$ & Aptian & $1453.2-1453.5$ & 0.2 & 1.8 & 0.57 & 13 & 0.22 & -27.0 & -22.1 & -4.9 & 102 & 679 & 577 \\
\hline $398 \mathrm{D}-112-2$ & L. Aptian & $1488.5-1489.0$ & 0.3 & 2.6 & 0.75 & 6 & 0.07 & -27.2 & -23.0 & -4.2 & 121 & 547 & 426 \\
\hline $398 \mathrm{D}-114-3$ & L. Aptian & $1509.0-1509.3$ & $<0.1$ & $<0.8$ & 0.43 & 22 & 0.52 & -26.7 & -23.3 & -3.4 & 115 & 491 & 376 \\
\hline $398 \mathrm{D}-118-5$ & L. Aptian & $1550.0-1550.5$ & $<0.1$ & $<0.8$ & 1.29 & 7 & 0.05 & -25.6 & -21.7 & -3.9 & 104 & 628 & 524 \\
\hline $398 D-120-5$ & U. Barremian & $1570.2-1570.6$ & 1.0 & 8.5 & 1.28 & 51 & 0.40 & -27.4 & -22.4 & -5.0 & 112 & 808 & 696 \\
\hline $398 \mathrm{D}-122-5$ & U. Barremian & $1587.0-1587.3$ & 3.5 & 28.8 & 2.20 & 43 & 0.20 & -29.3 & -25.6 & -3.7 & 73 & 1044 & 971 \\
\hline $398 \mathrm{D}-130-5$ & U. Barremian & $1665.0-1665.3$ & 1.9 & 16.0 & 1.98 & 26 & 0.13 & -27.9 & -24.2 & -3.7 & 61 & 889 & 828 \\
\hline
\end{tabular}

${ }^{\mathrm{a}}$ Sample insufficient or unsuitable for this determination. 


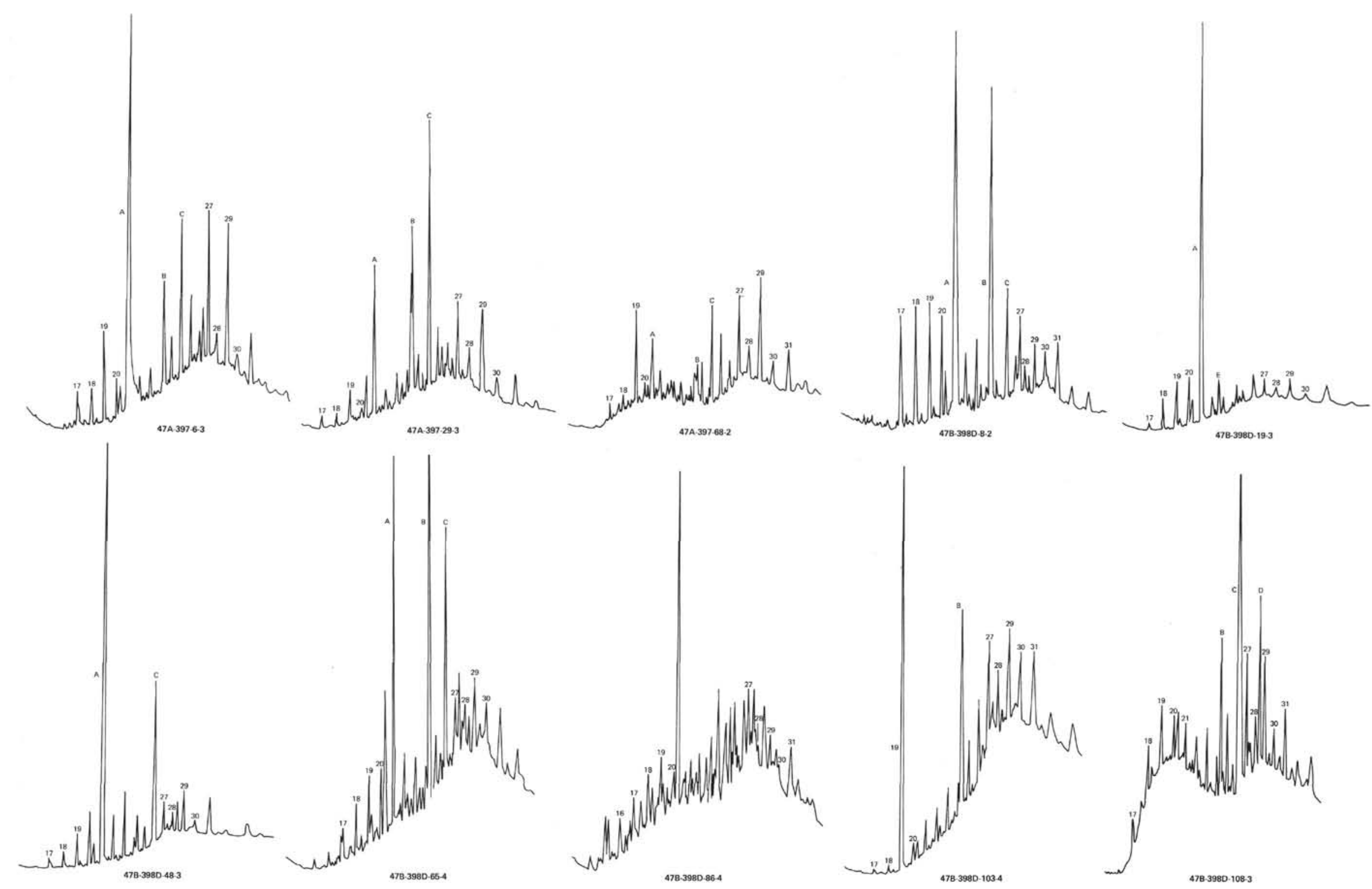

Figure 3. Gas chromatography profiles of the n-heptane soluble-lipid fraction from core samples (A) 397-6-3, (B) 397-29-3, and (C) 397-68-2 of Leg 47A; and (D) 398D-8-2, (E) 398D-19-3, (F) 398D-48-3, (G) 398D-65-4, (H) 398D-86-4, (I) 398D-103-4, and (J) 398D-108-3 of Leg 47B. 
through 398D-84-4 yield GC profiles similar to that shown in Figure $3 \mathrm{~g}$. Each has an odd predominance of $n$-alkanes in the range of $\mathrm{C}_{15}$ to $\mathrm{C}_{20}$ and $\mathrm{C}_{27}$ to $\mathrm{C}_{33}$ and, in most instances, $\mathrm{A}$ is the predominant peak. The GC profile of Section 389D86-4 (Figure $3 \mathrm{~h}$ ) contains a large number of non- $n$-alkanes of equal concentration and one large peak near $\mathrm{C}_{20}$. As typified by Section 398D-103-4 (Figure 3i), the GC profiles of Sections 398D-88-4 to 398D-106-5 are predominantly $n$-alkanes with the $\mathrm{C}_{19}$ peak increasing with depth. A single unresolved carbon maximum at $\mathrm{C}_{27}$ is observed in the profiles of these cores. The GC profile of Section 398D-108-3 (Figure 3j) contains a bimodal unresolved carbon distribution with maxima at $\mathrm{C}_{20}$ and $\mathrm{C}_{28}$ and an odd-carbon-number predominance of $n$-alkanes between $\mathrm{C}_{27}$ and $\mathrm{C}_{33}$.

The carbon isotopic composition of Unit 4 averages -28.2 $\delta^{13} \mathrm{CPDB}_{\mathrm{P}}$, which is generally lower than in previous units. The carbon isotopic composition of lipid averages $-28.7 \delta^{13}$ CPDB between the Cenomanian sediments (at a depth of $960.4 \mathrm{~m}$ ) and the Aptian (at $1385.7 \mathrm{~m}$ ). This composition remains constant at $-27.0 \pm 0.3 \delta^{13} \mathrm{CPDB}_{\mathrm{PB}}$ in the lower Aptian (at 1509.0 $\mathrm{m}$ ), increases to $-25.6 \delta^{13} \mathrm{CPDB}_{\mathrm{P}}$ in the lowermost Aptian (at $1550.0 \mathrm{~m}$ ), decreases to a low of $-29.3 \delta^{13}$ CPDB in the Barremian, and finally increases to $-27.9 \delta^{13} \mathrm{CPDB}$ at the bottom of the unit.

\section{DISCUSSION}

Samples from Holes 397 and 397A are predominantly hemipelagic marls low in organic matter. The amount of terrestrially derived organic matter admixed with that of marine origin varies considerably, as noted in the wide range of carbon isotopic composition of the lipid fractions and also in the shipboard lithology report. The maximum organic content is only 1.2 per cent, which is considerably below the 5 per cent value noted in the shipboard reports. Of the sections rich in organic matter $(70.5 \%)$, only the lower Miocene to Lower Cretaceous sediments contain more than a trace of lipid ( $>100 \mathrm{ppm})$. Even in these sections the lipid content is only a small portion of the total sediment, $248 \mathrm{ppm}$ maximum. The conversion of kerogen to lipid, as determined by the ratio of lipid to total organic carbon, is also low throughout the upper sections, and increases to a high of 2.5 per cent in the Lower Cretaceous. The odd-to-even predominance of $n$-alkanes from $\mathrm{C}_{25}$ to $\mathrm{C}_{33}$ is, in most cases, typical of distributions from recent sediments or sediments in an early stage of petroleum genesis.

The carbon isotopic composition of the lipid varies throughout the section from a low $\left(-29.6 \delta^{13} \mathrm{CPDB}_{\mathrm{PD}}\right)$ characteristic of a high terrestrial input, to a high $\left(-23.8 \delta^{13} \mathrm{CPDB}_{\mathrm{PD}}\right.$ which indicates an open marine environment. In general, the lipid with the lighter isotopic values are found in cores lean in lipid and have the least conversion of kerogen to lipid. The large difference between the lipid and kerogen isotopic composition suggests an early stage of genesis.

Carbonates from Hole 398D that are low in organic matter range from the uppermost sections to a depth of 1037.0 meters in Albian sediments. In contrast, claystones high in organic matter content occur from 1073.4 meters in the Albian to 1665.3 meters in the Early Cretaceous-Barremian. The latter sediments contain a large amount of terrestrially derived organic matter. Although the total organic content increases with depth and temperature, the total amount of lipid present and the conversion of kerogen to lipid never reaches an appreciable amount. The total conversion of or- ganic matter to lipid is low and averages only 0.88 per cent of the total organic matter present. The lipid carbon isotopic compositions of Units 1 through 3 average $-26.4 \delta^{13} C_{\text {PDB }}$ with a range of -24.6 to $-27.7 \delta^{13}$ СРDB. The difference between the isotopic compositions of lipid and kerogen is either positive or small, indicating that the kerogen contains a considerable portion of relatively non-reactive coal-like material mixed with marine-derived kerogen similar to that found in the Leg 40 Cape Basin sediments. In Unit 4, the lipid minus kerogen value is large and negative, suggesting that the lipid fraction is derived predominantly from terrestrial organic matter and that the kerogen consists of both marine and terrestrial active organic matter.

\section{CONCLUSIONS}

Geochemical investigations were conducted for two suites of cores from two different sites in the eastern part of the North and Middle Atlantic. Both locations are in the deep ocean at the edge of continental margins. The initial subbottom temperatures are considered too low for petroleum genesis; the sediment/water interface for both Sites 397 and $398 \mathrm{D}$ is $4.6^{\circ} \mathrm{C}$, while the initiation of petroleum genesis is believed to begin at approximately $50^{\circ} \mathrm{C}$. However, hydrocarbon gases up to $\mathrm{C}_{5}$, which are a consequence of diagenesis, are found in the shallowest cores at Site 397 , as noted in the initial shipboard reports. These gases result from either an upward migration from sediments that are in a more advanced stage of diagenesis, or from generation within the sediments. If the latter is true, then the low temperature cut-off probably varies according to the organic-type present, with $50^{\circ} \mathrm{C}$ representing only a stage in the genesis process where the rate of petroleum formation is appreciable.

The Lower Cretaceous in Hole $397 \mathrm{~A}$ is above $50^{\circ} \mathrm{C}$ and, thus, in the hypothetical petroleum-generating "window.", Moreover, the organic content for these sections is sufficient for the generation of petroleum. On-board ship and in our laboratory, certain indicators of petroleum genesis are noted, such as an increase in hydrocarbon gas concentration, ratio of $\mathrm{n}-\mathrm{C}_{5} / \mathrm{i}-\mathrm{C}_{5}$, conversion of kerogen to lipid, and lipid concentration. Other data, presented herein, indicate that genesis of petroleum is in a very early stage.

The Lower Cretaceous strata at Hole 398D are slightly deeper and higher in temperature than strata at Hole 397A. Although they contain facies that are high in organic matter, these sediments appear to have undergone very little diagenesis, as indicated by a lack of a lipid fraction and low conversion of kerogen to lipid. The organic matter present in these sediments is predominantly terrestrial and highly carbonaceous. It is diagenetically resistant to organic alteration and is a poor source of petroleum.

\section{ACKNOWLEDGEMENT}

The authors thank J.B. Foresman of Phillips Petroleum Company for his review and suggestions concerning the manuscript, and C.P. Elston for her help in obtaining and assembling data presented herein.

\section{REFERENCE}

Erdman, J.G. and Schorno, K.S., 1978. Geochemistry of carbon: Deep Sea Drilling Project Leg 40. In Bolli, H.M., Ryan, W.B.F., et al., Initial Reports of the Deep Sea Drilling Project, Supplement to Volumes 38, 39, 40, and 41: Washington (U.S. Government Printing Office), p. 651-658. 